\title{
Alternative fuels and power systems to reduce environmental impact of support vessels
}

Cdr (E) dr. ir. Rinze Geertsma, CEng, MIMarEST ${ }^{a, b}$, ir. M. Krijgsman ${ }^{c}$

${ }^{a}$ Netherlands Defence Academy; ${ }^{b}$ Delft University of Technology; ${ }^{c}$ MARIN

*Corresponding author. Email: r.d.geertsma@tudelft.nl

\section{Synopsis}

The Netherlands Ministry of Defence have declared the ambition to reduce its fossil fuel dependency by at least $20 \%$ in 2030 and by at least $70 \%$ in 2050 . For the Royal Netherlands Navy (RNLN), these targets seem more stringent than the initial strategy on greenhouse gas reduction for ships agreed by IMO, which aims for $50 \%$ reduction in total annual global shipping emission by 2050 . The RNLN is currently investigating the replacement of a series of support vessels, 5 ships between 1000 and 2000 tons that perform hydrographic, submarine exercise support, civil support and seamanship training operations. These vessels perform support operations, are not volume critical in their design and have a limited mission duration of 2 to 3 weeks, and thus seem good candidates for alternative fuels and alternative power systems, such as fuel cells and batteries, that have emissions with a minimum impact on the environment.

This study presents a novel approach to compare various alternative energy carrier and power system options with the Ships Power and Energy Concept (SPEC) exploration tool. We first introduce the baseline vessel and introduce the various fuels and technologies considered. We consider marine diesel oil as a baseline and alternative energy carriers hydrogen, methanol or ammonia and batteries. We review the fuels, their current and future availability and their impact on the environment. Moreover, we review the power system technologies, considering diesel generators running on marine diesel oil, methanol, ammonia or dimethyl ether, fuel cells running on hydrogen or methanol and batteries as the only power supply, recharged when ashore. Furthermore, we review power system designs with the combinations of fuel and power supply identified above and will consider: the mass and volume of the power system configurations and energy storage, fuel or batteries; the estimated capital and operational expenditure; technology readiness level; logistic availability of the fuel; and the estimated yearly $\mathrm{CO} 2$ emissions. Electrical propulsion with electrical power supply from internal combustion engines running on methanol appears a mature and cost-effective candidate to achieve the reduction target of $70 \%$ reduction in $\mathrm{CO}_{2}$ emission and its related dependancy on fossil fuels, with a $10 \%$ increase in capital cost and double fuel cost.

Keywords: Energy efficiency; Ship propulsion; Alternative fuels; Power generation; Fuel cells; Batteries

प

\section{Introduction}

The Royal Netherlands Navy (RNLN) have declared the ambition to reduce its fossil fuel dependency by at least $20 \%$ in 2030 and by at least $70 \%$ in 2050 (Netherlands Ministry of Defence, 2015, Schulten et al., 2015, 2017; van de Ketterij, 2018), targets that seem more stringent than the initial strategy on greenhouse gas reduction for ships agreed by IMO, which aims for 50\% reduction in total annual global shipping emission by 2050 (IMO MEPC 72 . 2018). Schulten et al. (2017) conclude that, for future frigates the ambitions of the Operational Energy Strategy (OES) in 2030 can be met with a combination of technological improvements and changes in the operational doctrine and crew behaviour. While the design of surface combatants is very volume critical, alternative fuels with a significantly reduced energy density, appear unfeasible for surface combatants, or would at least heavily reduce its operational range. The Royal Netherlands Navy also operates support vessels, 5 ships between 1000 and 2000 tons that perform hydrographic, submarine exercise support, civil support and seamanship training operations. As these vessels are intensively utilised, they account for around $10 \%$ of the total fossil fuel usage of the fleet. These vessels need to be replaced over the next two decades, and they provide an opportunity to contribute a significant reduction of the dependancy on fossil fuels for the navy and reduce the impact of naval operations on the environment.

Societal pressure and the IMO's greenhouse gas reduction strategy has led to increasing research into alternative fuels for shipping (Taljegard et al., 2014, Deniz and Zincir, 2016, Svanberg et al., 2018, Ammar, 2019, Evrin and Dincer, 2019; van de Ketterij, 2018). Economic studies (Taljegard et al., 2014; Deniz and Zincir. 2016) suggest that in the short term LNG provides a cost effective alternative for heavy fuel oil for transport shipping that significantly reduces hazardous emissions such as sulfur, $\mathrm{PM}$ and $\mathrm{NO}_{\mathrm{x}}$. However, $\mathrm{LNG}$ is a fossil fuel and when considering

Authors' Biographies

Cdr (E) dr. ir. Rinze Geertsma currently is senior officer energy and smart maintenance at the Defence Materiel Organisation of the Netherlands Ministry of Defence and part-time lecturer and researcher at Delft University of Technology and Netherlands Defence Academy on energy and maintenance. He has previously been Marine Engineering Officer of HNLMS de Ruyter and HNLMS Tromp. Earlier experience includes research and development project managing, system and project engineering and in service support.

ir. Moritz Krijgsman is responsible for Hydro systems at MARIN. His team develops design methods and conceptual ship designs for the maritime energy transition. Moreover, a scaled physical test setup, the Zero Emission Laboratory, and a numerical model of future engine room systems are developed and built. He has served as Marine Engineering Officer on RNLN diesel-electric submarines, as engineering manager of the naval dockyard in Den Helder and of Smit Power Transformers and as director Technology and Innovation of Alewijnse Marine Systems. 


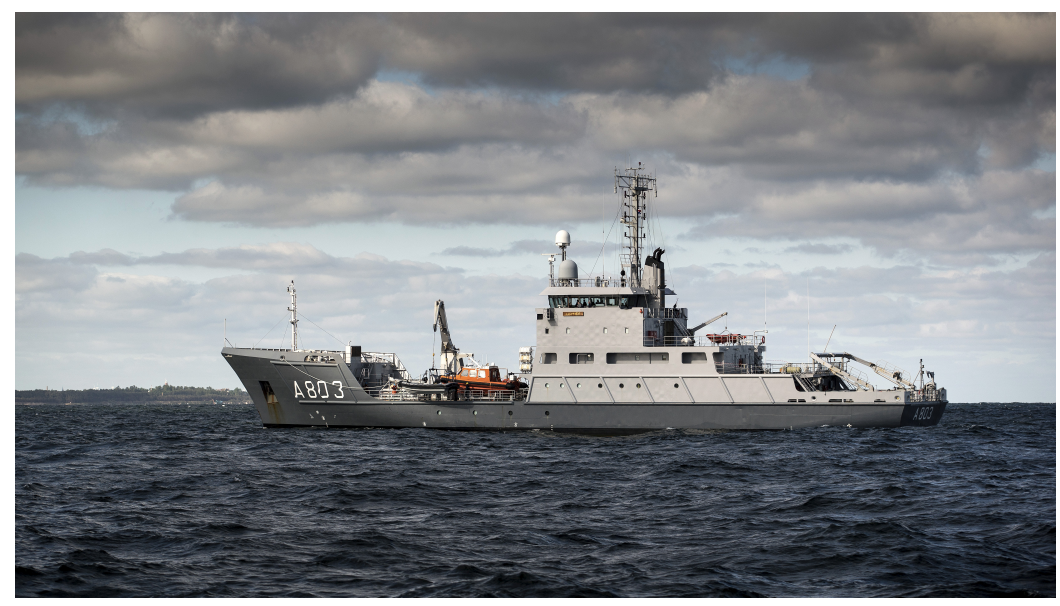

Figure 1: Hydrographic survey vessel Zr. Ms. Luymes.

the whole supply chain, might lead to an increased global warming effect due to methane slip. Methanol can be produced from renewable feedstock, thus can reduce the greenhouse gas emission impact by up to $89 \%$ for methanol from black-liquor gasification integrated with pulp mill, according to the European Energy Directive (European Union, 2018). As methanol from renewable feedstock is no fossil fuel, the dependancy of fossil fuel can thus also be reduced. In this paper, we will therefore consider the reduction of $\mathrm{CO}_{2}$ synonymous to the reduction of $\mathrm{CO}_{2}$ emissions with the reduction as proposed in the European Energy Directive. (European Union, 2018). Ammar (2019) concludes that for a cellular container ship, conversion to methanol leads to a $40 \%$ increase in fuel cost, which could be recovered by slow steaming at $28 \%$ reduced speed. This would lead to a significant reduction in hazardous emissions and $\mathrm{CO}_{2}$. However, he considers methanol from fossil origin, so no reduction in fossil fuel dependancy is achieved. Svanberg et al. (2018) concludes that using methanol from renewable feedstock is viable from the supply chain point-of-view, but that the cost currently prohibits its commercial implementation, even though the global warming impact could be reduced by up to $89 \%$. While methanol still contains carbon atoms, ammonia is free of carbon and thus does not produce any $\mathrm{CO}_{2}$. Therefore, ammonia might be a truly $\mathrm{CO}_{2}$ free fuel that is already produced on a large scale. Finally, hydrogen is considered as a truly renewable fuel when produced from renewable energy. Evrin and Dincer (2019) review an integrated hydrogen fuel cell system for ships and conclude such a hydrogen fuelled system can provide renewable energy for ships with a short refuelling interval of around 10 hours. In this study, we thus consider the current fuel for the navy, marine diesel oil (MDO), methanol, ammonia and hydrogen.

Diesel engines provide the majority of power for the propulsion and auxiliary power of ships. While the efficiency has increased over the years, it reaches its maximum potential. Therefore, further development of diesel engines is not expected to contribute significantly to the $\mathrm{CO}_{2}$ reduction targets, unless they run on renewable fuels. Alternatively, fuel cells have demonstrated efficiencies that are much higher than diesel engines (van Biert et al. 2016). Therefore, their application on ships could potentially lead to significant $\mathrm{CO}_{2}$ reduction, in particular when combined with non-fossil fuels, such as hydrogen. Batteries recharged from the grid with renewable energy can provide truly emission-less power and the first ferries, such as MV Ampere, demonstrate this potential (Geertsma et al., 2017b; Kalikatzarakis et al., 2018). Therefore, in this study, we consider fuel cells and batteries as alternative power sources.

While many studies have investigated the economic viability (Taljegard et al., 2014; Deniz and Zincir, 2016; Ammar. 2019) and the supply chain (Svanberg et al., 2018) of alternative fuels, this study focuses on the impact of alternative fuels and power supply for specific ships, support vessels of the RNLN, which are also representative for short sea shipping vessels. We propose a novel methodology that investigates the trade-off between fossil fuel dependancy and $\mathrm{CO}_{2}$ emissions, ship design impact in volume and weight, capital and operational cost and technical and logistical maturity for a number of alternative fuels and their associated power systems.

The structure of the paper is as follows. In Section 2, we introduce the case study of the support vessels and the baseline design. In Section 3, we introduce the Ship Power and Energy Concept (SPEC) exploration methodology, before introducing the various alternative fuels and power systems. We then discuss the results of the methodology for the case study support vessels in Section 4, before summarising the conclusions in Section 5

\section{Support vessels}

The support vessels of the RNLN consist of five vessels that perform hydrographic survey operations (Zr. Ms. Luymes, shown in Figure 1, and Zr. Ms. Snellius), submarine exercise support (Zr. Ms. Mercuur), coastguard 
Table 1: Replacement planning of support vessels (Defensie, 2018)

\begin{tabular}{lll}
\hline Ship class & Current vessels & Planned replacement \\
\hline Training vessel & MV Kinsbergen & 2025 \\
\hline Submarine exercise support vessel & Zr. Ms. Mercuur & 2026 \\
\hline Support vessel & Zr. Ms. Pelikaan & 2030 \\
\hline Hydrographic survey vessels & Zr. Ms. Luymes and Zr. Ms. Snellius & 2033 \\
\hline
\end{tabular}

Table 2: Principal parameters of hydrographic survey vessels

\begin{tabular}{lll}
\hline Parameter & Value & Value for reduced range \\
\hline Transit speed & $12 \mathrm{kts}$ at seastate 4 & \\
\hline Maximum speed & $13 \mathrm{kts}$ & \\
\hline Range at transit speed & $12000 \mathrm{~nm}$ & $5000 \mathrm{~nm}$ \\
\hline Stored energy & $3750 \mathrm{MWh}$ & $1500 \mathrm{MWh}$ \\
\hline Power mission and auxiliary systems & $350 \mathrm{~kW}$ & \\
\hline
\end{tabular}

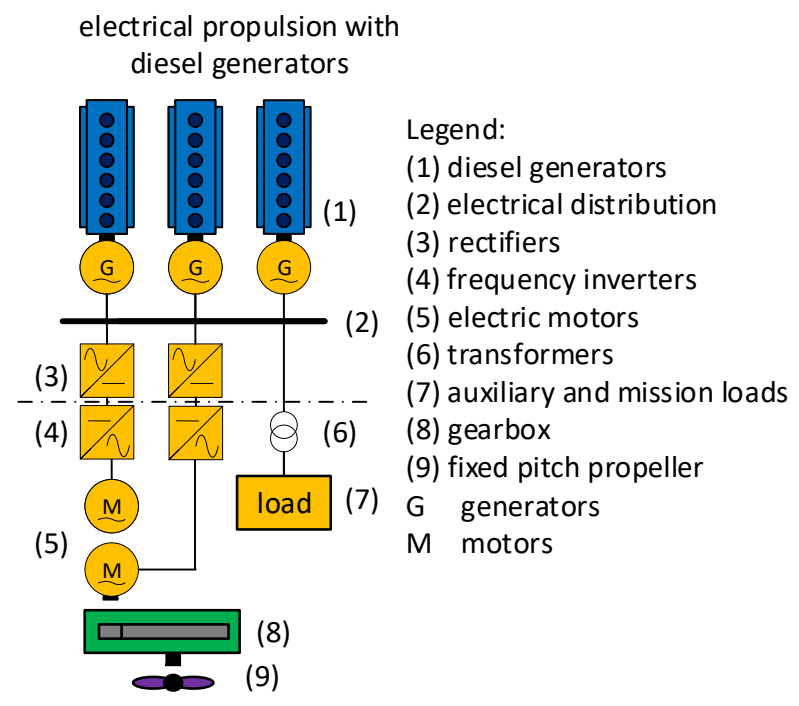

Figure 2: Schematic representation of electrical propulsion and power generation plant considered in this study.

and civil support (Zr. Ms. Pelikaan) and navigation training (Zr. Ms. Kinsbergen). In the defence bill 2018, the replacement of these vessels is announced according to the schedule shown in Table 1. Initial studies have suggested that cost savings and efficiency gains can be achieved by designing one class of vessels, based on a single hull and system design. The current design of the hydrographic survey vessels is representative for this design. Therefore, we use the current hydrographic survey vessels as the baseline design in this study. Figure 1 shows Zr. Ms. Luymes during operations and Table 2 shows the principal parameters of the hydrographic survey vessels, that are used as a baseline for this study.

The propulsion and power generation plant of the hydrographic survey vessels consists of electrical propulsion with combustion power supply from diesel generators running on F-76 marine diesel oil (MDO), as illustrated in Figure 2. While hybrid propulsion with an electric drive in parallel with the main engine can provide energy savings (Schulten et al., 2017, van de Ketterij, 2018), this study considers electrical propulsion, because it allows easy integration of alternative fuels and power sources. Moreover, electrical propulsion would allow modular replacement of power generation units with units on alternative fuels or alternative technology. Finally, the methodology is proposed for the early concept design, before more detailed analysis with dynamic models that include part load efficiencies and dynamic effects is performed with dynamic models (Geertsma et al. 2017b).

The most important aspect of the ship operations to determine operating cost is the operating profile. The operating profile of the support vessels in general and the hydrographic survey vessels in particular consists of slow speed manoeuvring and position keeping, for example when entering port, hydrographic operations, which is 
Table 3: Operating profile of hydrographic survey vessels

\begin{tabular}{llll}
\hline Type of operation & Speed & $\begin{array}{l}\text { Time in opera- } \\
\text { tion Power }\end{array}$ \\
\hline Low speed and station keeping & $4 \mathrm{kts}$ & $15 \%$ & $141 \mathrm{~kW}$ \\
\hline Hydrographic operations & $9 \mathrm{kts}$ & $40 \%$ & $436 \mathrm{~kW}$ \\
\hline Economic transit & $9 \mathrm{kts}$ & $15 \%$ & $436 \mathrm{~kW}$ \\
\hline High speed transit & $12 \mathrm{kts}$ & $25 \%$ & $880 \mathrm{~kW}$ \\
\hline Maximum speed & $13 \mathrm{kts}$ & $5 \%$ & $1150 \mathrm{~kW}$ \\
\hline
\end{tabular}

Table 4: Fuels' absolute and contained energy density by volume and mass

\begin{tabular}{lllll}
\hline Fuel & $\begin{array}{l}\text { Absolute } \\
\text { energy density } \\
\text { by volume in [MJ//] }\end{array}$ & $\begin{array}{l}\text { Absolute } \\
\text { energy density } \\
\text { by mass in [MJ/kg] }\end{array}$ & $\begin{array}{l}\text { Contained } \\
\text { energy density } \\
\text { by volume in [MJ/l] }\end{array}$ & $\begin{array}{l}\text { Contained } \\
\text { energy density } \\
\text { by mass in [MJ/kg] }\end{array}$ \\
\hline Diesel (F-76) & 36 & 42 & 31 & 31 \\
\hline Methanol & 15.6 & 19.7 & 14 & 17 \\
\hline Ammonia & 11.3 & 18.4 & 10 & 14 \\
\hline Hydrogen & 9.2 & 120 & 5 & 9.3 \\
\hline Batteries & 0.5 & 0.4 & 0.4 & 0.3 \\
\hline
\end{tabular}

typically performed at $9 \mathrm{kts}$, economic transit, also at $9 \mathrm{kts}$, high speed transit at $12 \mathrm{kts}$ and maximum speed sailing at $13 \mathrm{kts}$. The time spent at the various speeds is shown in Table 3 .

\section{Ship power and energy concept methodology}

Due to environmental awareness and ever tighter regulations the maritime world faces an enormous challenge to change from fossil fuels to energy sources that cause minimal emission of greenhouse gasses as well as harmful gasses such as $\mathrm{NO}_{\mathrm{x}}$ and $\mathrm{SO}_{\mathrm{x}}$, and particle matter. The impact of this transition to cleaner power sources goes much further than simply replacing the old diesel engine with a modernised one running on a cleaner fuel. A multitude of alternative energy sources can be considered, as well as the equipment to convert them into useable power. Beside financial effects the consequences, however, reach as far as new propulsions arrangements, changes for fuel storage, crew capabilities, necessary shore infrastructure and public support.

Information about alternative power is available from publications and exhibitions, conferences and symposia. For some applications vendors do offer commercial solutions, others are still very experimental. A clear picture is hard to get because information is often fragmented and offers a confusing perspective. This makes choosing the optimal technology for specific maritime operations a difficult task, and implementing the consequences in the ship design a complicated challenge.

Compared to fossil fuels, alternative energy carriers have several different properties, as illustrated in Table 4. Therefore, the complete energy and power chain from tank to propulsion has to be designed outside the conventional framework. The variety of possible energy carriers, the power conversions and the appropriate propulsion and power configurations require a holistic conceptual design method, the Ship Power and Energy Concept design methodology.

Starting point for the SPEC methodology are the operational requirements of the ship as well as criteria, objectives and priorities of the owner, as discussed for the case study support vessel in Section 2. Using a database with properties of all sorts of energy sources, as presented in Table 5 , and its equipment and storage requirements, presented in Table 6, SPEC metholodogy ranks the most suitable solutions to set up a ship with low or zero emissions. The criteria cover all sorts of technical, economic, environmental and societal aspects. Initial effects during design and building are considered, as well as long term effects during operations. By changing the scores and weights of the criteria, future estimates can be made using multiple scenarios for the maritime energy transition. The output of SPEC is an independent, future proof and operations based ranking of a wide selection of solutions.

For the most attractive solutions, a conceptual design of a potential ship is made, including a general arrangement of equipment, weight, volume and cost of the engine room systems and bunker spaces and the autonomy that can be obtained. Figure 3 shows an example of the geometrical concept of the electrical propulsion with power supply from internal combustion engines running on methanol and its methanol bunker for the case study vessel. 
Table 5: Energy sources' capital and operational expenditure (CAPEX and OPEX), technology readiness level (TRL) and equivalent greenhouse gas emissions (GHG)

\begin{tabular}{lllll}
\hline Fuel & $\begin{array}{l}\text { CAPEX } \\
\text { kEUR/MWh }\end{array}$ & $\begin{array}{l}\text { OPEX } \\
\text { kEUR/MWh }\end{array}$ & TRL & $\begin{array}{l}\text { GHG } \\
\text { tCO }_{\mathbf{2}} \text { /t }\end{array}$ \\
\hline Diesel (F-76) & 0.6 & 0.087 & 9 & 3.2 \\
\hline Methanol & 0.7 & 0.1 & 7 & 1.3 \\
\hline Methanol from renewable feedstock & 0.7 & 0.17 & 7 & 0.4 \\
\hline Ammonia & 7.65 & 0.12 & 5 & 0 \\
\hline Hydrogen & 1.5 & 0.07 & 5 & 0 \\
\hline Batteries & 800 & 0.07 & 9 & 0 \\
\hline
\end{tabular}

Table 6: Power conversion system capital expenditure (CAPEX), overall system efficiency $(\eta)$, and technology readiness level (TRL)

\begin{tabular}{llll}
\hline Fuel & $\begin{array}{l}\text { CAPEX } \\
\text { kEUR/MW }\end{array}$ & $\eta$ & TRL \\
\hline Power supply from internal combustion engines & 1450 & $34 \%$ & 9 \\
\hline Power supply from PEM fuel cells with $\mathrm{H}_{2}$ fuel & 3900 & $41 \%$ & 6 \\
\hline Power supply with PEM fuel cells with methanol fuel & 4000 & $38 \%$ & 5 \\
\hline Power supply with SOFC fuel cell with methanol fuel & 10000 & $45 \%$ & 4 \\
\hline Power supply with batteries energy storage & 1200 & $82 \%$ & 9 \\
\hline
\end{tabular}

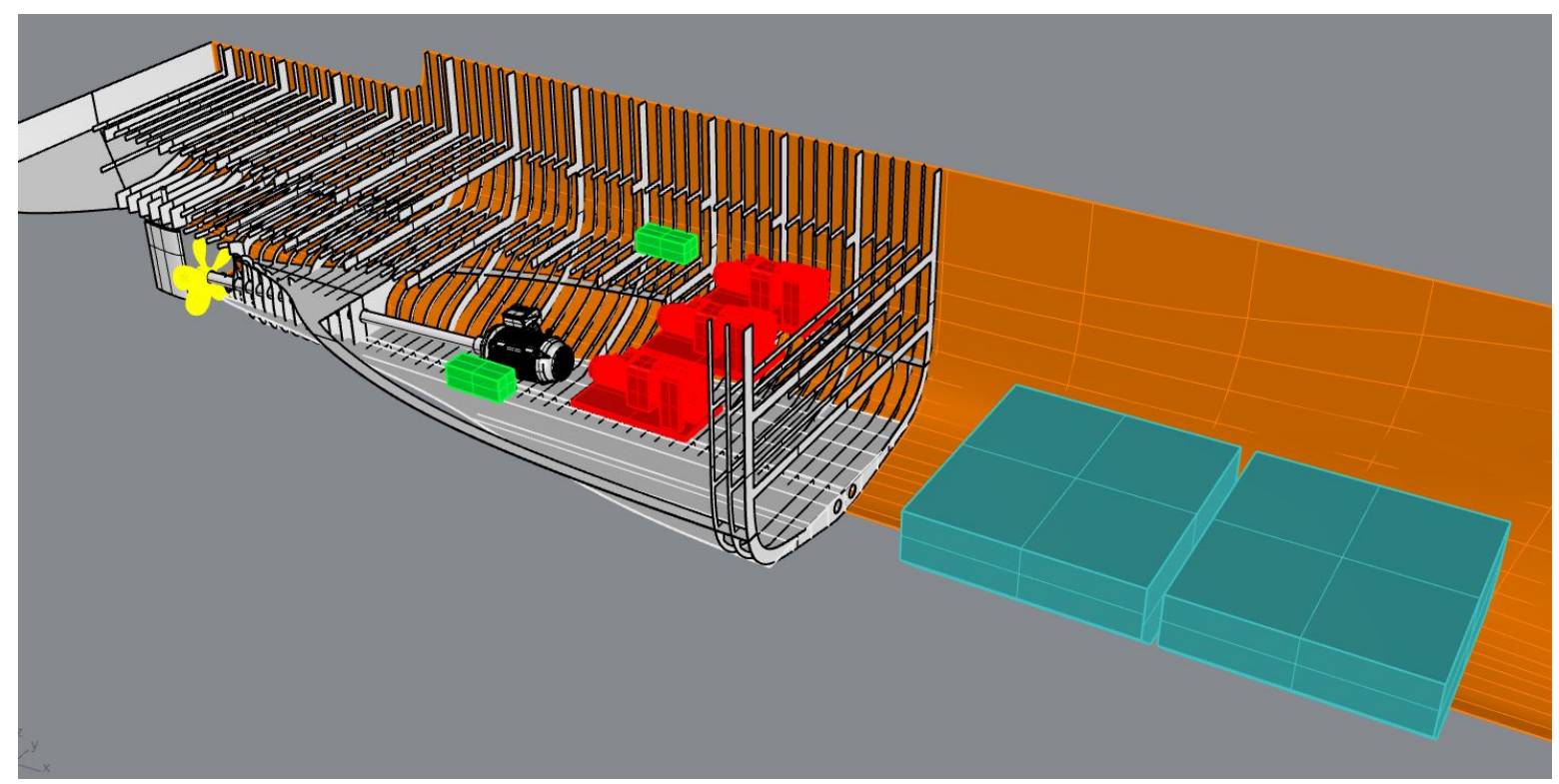

Figure 3: Example of a conceptual design of bunker and engine room of a methanol ICE Electric configuration for the case study support vessel.

After the SPEC analysis, a technical configuration can be scale tested in MARIN's future $100 \mathrm{~kW}$ Zero Emission and Climate Neutral Laboratory (ZEL), where robustness and reliability of the propulsion and power systems that encounter disturbances coming from sea and manoeuvring conditions can be investigated. The physical ZEL has a digital twin, the virtual ZEL (VZEL), for fast verification and optimisation of the systems design. In the VZEL environment a digital twin of the technical configuration of the potential ship can be created for model based systems engineering and life time support. 
Table 7: Results of ship power and energy concept exploration for hydrographic support vessels

\begin{tabular}{|c|c|c|c|c|c|c|c|}
\hline Option & $\begin{array}{l}\text { Mass } \\
\text { [ton] }\end{array}$ & $\begin{array}{l}\text { Volume } \\
{\left[\mathrm{m}^{3}\right]}\end{array}$ & $\begin{array}{l}\text { CAPEX power } \\
\text { \& propulsion } \\
\text { [MEUR] }\end{array}$ & $\begin{array}{l}\text { OPEX power } \\
\text { \& propulsion } \\
\text { [MEUR/year] }\end{array}$ & TRL & $\begin{array}{l}\text { Logistic } \\
\text { maturity }\end{array}$ & $\begin{array}{l}\text { Eq. } \mathrm{CO}_{2} \\
\text { [kton / year] }\end{array}$ \\
\hline Diesel (F-76) & 188 & 223 & 3.6 MEUR & 1.09 MEUR & 9 & very good & 3.4 \\
\hline Diesel (F-76) long range & 449 & 484 & 4.9 MEUR & 1.09 MEUR & 9 & very good & 3.4 \\
\hline PEM liquid $\mathrm{H}_{2}$ & 640 & 1300 & $\sim 9$ MEUR & 2.6 MEUR & 5 & poor & 0 \\
\hline PEM methanol & 383 & 605 & $\sim 8$ MEUR & 2.2 MEUR & 6 & reasonable & 1 \\
\hline SOFC methanol & 383 & 605 & 20 MEUR & 1.9 MEUR & 5 & reasonable & 1 \\
\hline ICE methanol & 332 & 434 & 3.9 MEUR & 2.5 MEUR & 7 & reasonable & 1 \\
\hline $\mathrm{ICE} \mathrm{NH} 3$ & 415 & 613 & 5 MEUR & 1.6 MEUR & 5 & reasonable & 0 \\
\hline
\end{tabular}

\section{Results}

The results of the concept design module of the ship power and energy concept methodology (SPEC) provide the mass, volume, capital and operational expenditure of the vessel related to the propulsion and power generation system, and technology readiness level, maturity of the logistic supply chain and the estimated equivalent $\mathrm{CO}_{2}$ emission from the vessels as a measure for the dependancy on fossil fuels. For the biologically produced methanol from waste streams, we have assumed a mixture of waste streams that leads to a reduction in equivalent $\mathrm{CO}_{2}$ emissions of $70 \%$, which is conservative compared to the maximum $\mathrm{CO}_{2}$ reduction of $89 \%$ that can be achieved by production of methanol from black liquor (European Union, 2018). The results are presented in 7 and are discussed per technology in the following subsections.

\subsection{Reference design with electrical propulsion and combustion power supply}

The reference design consists of electrical propulsion with combustion power supply from diesel generators running on marine diesel oil, which is referred to as F-76. The existing hydrographic survey vessels are considered as the baseline. However, these vessels have an operating range of $12000 \mathrm{~nm}$ at transit speed, which coincides with approximately 7 weeks of operation according to the operating profile in Table 3 . The hydrographic survey vessels are intensively used and operate continuously with multiple crews that change over every 2 to 3 weeks during a port visit, when the ships can also be refuelled. In order to reduce the impact of the reduced energy density of alternative energy carriers, we thus reduced the operating range of the alternative concept designs to 5000nm at transit speed, which coincides with up to 3 weeks of operation. The results in Table 7 show both the results for the current hydrographic survey vessels with a range of $12000 \mathrm{~nm}$ and the results for hydrographic survey vessels with a reduced range of $5000 \mathrm{~nm}$.

\subsection{Electrical propulsion with stored power supply}

Electrical propulsion with stored power supply has Technology Readiness Level (TRL) 9 and is applied to ferries with a short sailing profile, such as MV Ampere (Geertsma et al., 2017a). The energy density for Li-ion battery technology ranges between 75 and 200 [kWh/ton] (Mutarraf et al., 2018) and commercially widely available Li-NMC batteries have an energy density of 80 [kWh/ton]. Thus, energy storage of 3750 [kWh], required for the reduced range of 5000 [nm], would require a mass of 20000 to 58000 ton, which is at least ten times the weight of the baseline design of the current HOV. Therefore, for an operating profile of 2 weeks batteries are considered unfeasible and the concept is not included in Table 7. In general, electrical propulsion with stored power supply can be considered for ships with an operating profile of up to 1 day with a low power requirement or for longer operating profiles with an extremely low power requirement.

\subsection{Power supply from PEM fuel cells on hydrogen}

The low temperature polymer electrolyte membrane (LT-PEMFC) fuel cell with hydrogen fuel has been applied to submarines in Germany and canal-cruise vessels in Amsterdam (van Biert et al., 2016; Psoma and Sattler, 2002). The main challenge for application of hydrogen-fuelled LT-PEM fuel-cells is the storage of large amounts of hydrogen. While the storage of hydrogen as a liquid achieves the highest volume density, the TRL for storing large quantities is low at TRL 5, as all maritime applications use compressed storage currently and safety implications of liquid storage need to be investigated (Tronstad et al., 2017). Similarly, the logistic maturity of the logistic supply chain is poor. Even when storing hydrogen in liquid form, the required storage volume is 6 times the required volume for F-76 diesel oil. The extra required volume would result in a large ship design impact with 


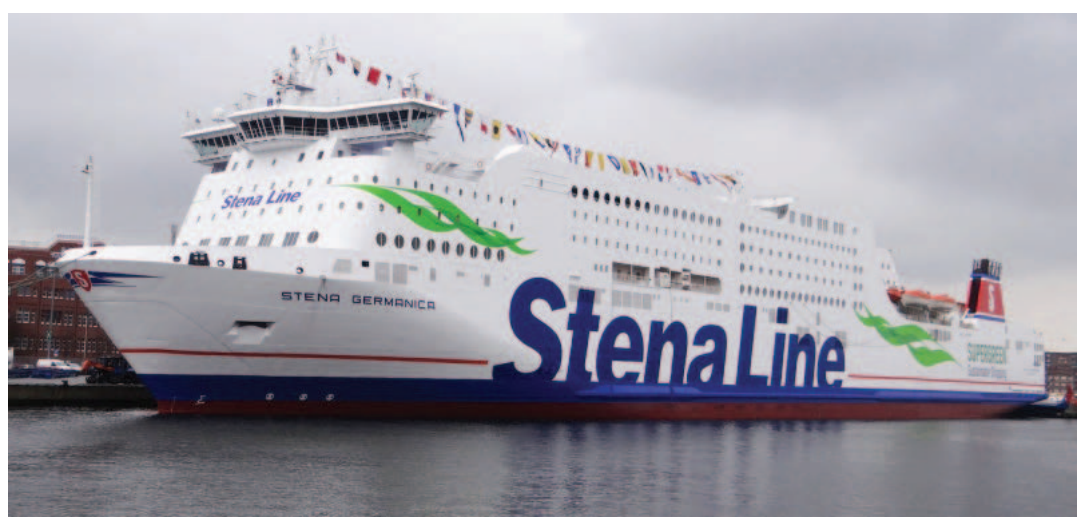

Figure 4: Ro-pax ferry Stena Germanica has been converted to methanol, from (Andersson and Salazar. 2015).

the associated extra cost. Moreover, as the current cost of fuel cells is relatively high, the capital expenditure is high, at an estimated value of 9 MEUR. Also, the cost of hydrogen is higher than fuels such as diesel oil, and ammonia and slightly more expensive than biologically produced methanol. The improved efficiency of fuel cells does not compensate sufficiently for the higher system efficiency. The main advantage of application of fuel cells on hydrogen, produced from renewable power, is its truly zero $\mathrm{CO}_{2}$ emissions.

\subsection{Power supply from PEM fuel cells on methanol}

The advantage of using methanol as a fuel for the PEM fuel cell, is that the storage weight and volume for the reduced range fits in the original fuel tank volume and weight. Moreover, the logistic maturity of handing methanol is reasonable, and the equivalent $\mathrm{CO}_{2}$ reduction can achieve a $30 \%$ reduction for biologically produced methanol with an operating cost up to twice the baseline cost due to the higher system efficiency. However, technical maturity of methanol reformer technology currently only at TRL 6, all-though under development in Germany. This also leads to high capital expenditure, but commercial development of fuel cells for commercial application in other fields might reduce the cost significantly over the next decade.

\subsection{Power supply from SOFC fuel cells on methanol}

Compared to PEM fuel cells, Solid Oxide Fuel Cells (SOFC) on methanol can achieve higher efficiencies, thus reducing operating cost by $14 \%$. However the current TRL and high capital expenditure, currently prohibits their maritime application at MW scale.

\subsection{Power supply from internal combustion engines on methanol}

Electrical propulsion with power supply from internal combustion engines on methanol has technology readiness level 7, as prototype systems have been demonstrated in the maritime environment with the Stena Germanica ro-pax ferry, illustrated in Figure 4, and a number of new-build methanol tankers (Andersson and Salazar. 2015). In the Netherlands, the Green Maritime Methanol project, which consists of a large number of shipyards, integrators, engine suppliers, knowledge institutes and classification societies, is investigating the application of methanol as an alternative marine fuel and is planning to test a number of engines on methanol. Thus, power supply from internal combustion engines on methanol is feasible, in particular if the dynamic loading of methanol combustion engines and its integration in a power system are further investigated. When methanol is produced from renewable sources, it can reduce the equivalent $\mathrm{CO}_{2}$ emissions by $70 \%$ at an increased operational expenditure of 2.5 [MEUR/year]. In future, further reduction of environmental impact is feasible, if synthetically produced methanol becomes available. While the required volume is 2.3 times the volume for F-76 diesel, additional mass and volume is required over F-76 diesel for the same range, but the required mass and volume at reduced range fits within the mass and volume of the original design and therefore is feasible. The capital expenditure is estimated to be $10 \%$ higher than with diesel fuel, due to changes on the engines, additional requirements for safe storage and transportation of the fuel, with double piping and an additional requirement for batteries for load levelling, as dual fuel and methanol engines might be more sensitive to dynamic loading. Moreover, the operational cost are estimated twice the cost of power supply on diesel fuel, due to the production cost of methanol from renewable methanol, which is estimated to be double the cost of F-76 diesel fuel. With the proposed replacement schedule in Table1, assuming the support vessels initially sails with one engine on methanol for derisking and is converted in 2030, the total relative fossil fuel dependancy and equivalent $\mathrm{CO}_{2}$ emssions with power supply from internal combustion engines on methanol with a $70 \%$ equivalent $\mathrm{CO}_{2}$ reduction is shown in Figure 5 


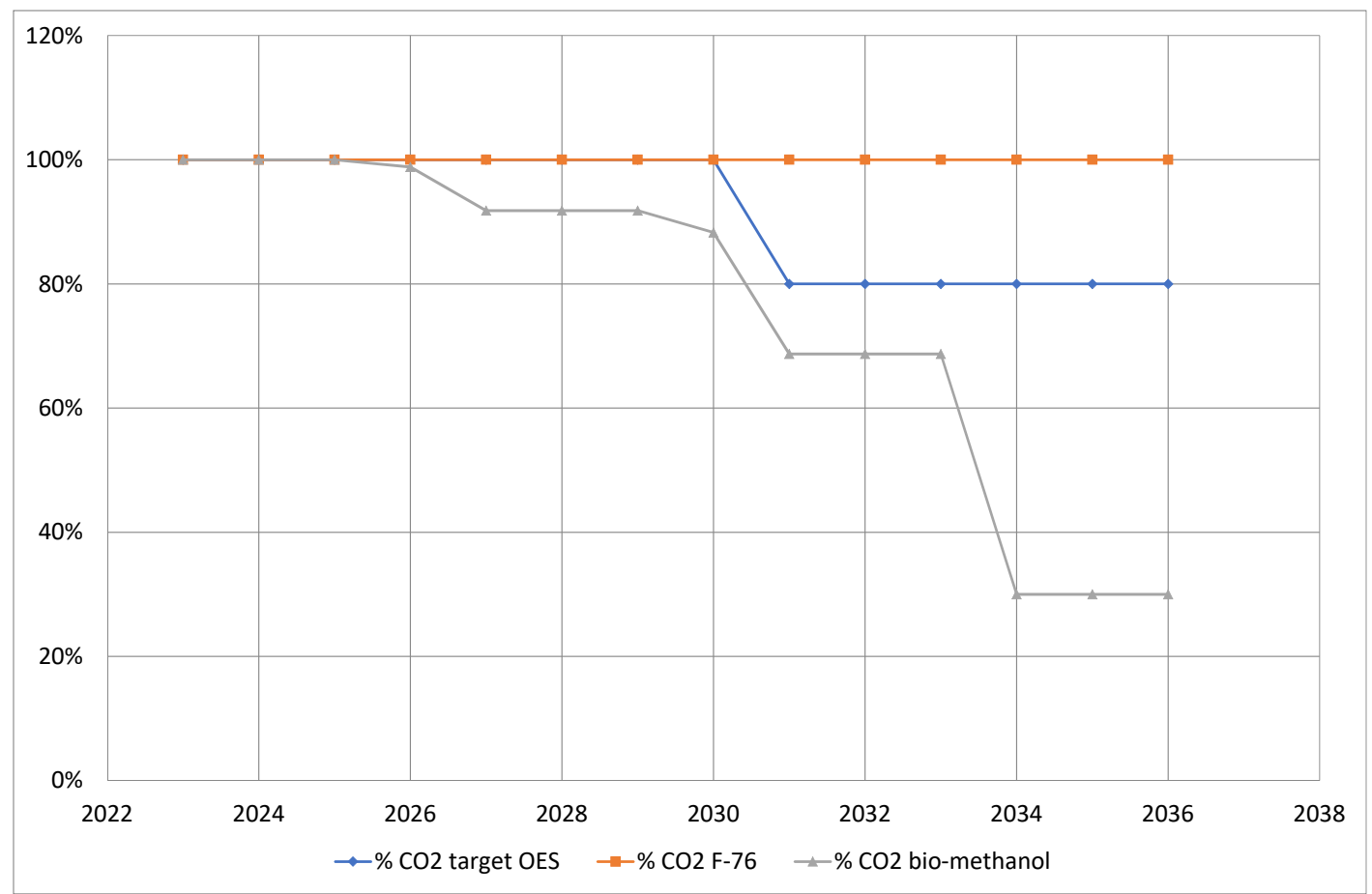

Figure 5: Relative fossil fuel dependancy and equivalent $\mathrm{CO}_{2}$ emissions with $70 \%$ reduction from bio-methanol on renewed support vessel fleet, according to Table 1

\subsection{Power supply from internal combustion engines on ammonia}

While methanol contains carbon atoms, ammonia, $\mathrm{NH}_{3}$, contains no carbon and therefore can completely rule out $\mathrm{CO}_{2}$ emissions. While ammonia is hazardous it is handled at large scale in the chemical industry and therefore can be considered reasonably logistically mature. However, maturity of engines running on ammonia is TRL 5, with a number of engine manufacturers currently investing in development of engines running on ammonia. Nevertheless, due to the current limited availability of engines running on ammonia and the challenges their development faces, we consider its application unfeasible in the short term.

\section{Conclusions and further research}

In this paper, a novel methodology has been proposed to review power system designs and alternative fuels or energy carriers to consider its impact on the following aspects: the mass and volume of the power system configurations and energy storage, fuel or batteries; the estimated capital and operational expenditure; technology readiness level; logistic availability of the fuel; and the estimated yearly $\mathrm{CO} 2$ emissions. The analysis for a case study support vessels of 1000 to 2000 tons shows that for ships with an operating profile of 2 to 3 weeks, batteries are unfeasible, and solid oxide fuel cells (SOFC) and hydrogen fuels are currently insufficiently mature. Methanol, in particular when produced from renewable feedstock, appears a logistically and technically mature fuel. Methanol as a fuel for internal combustion engines can reduce $\mathrm{CO}_{2}$ emissions by $70 \%$ for $10 \%$ higher capital cost and $100 \%$ increased fuel cost. While polymer electrolyte membrane (PEM) fuel cells and in the longer term SOFC's can further reduce environmental impact and operating cost due to their higher system efficiency, their maturity and cost currently prohibit their large scale application on ships of 1000 to 2000 tons. Future work is required to investigate the dynamic loading of methanol combustion engines and their integration in a power system to further reduce the risk of implementation and increase TRL to level 9, for example in the proposed Zero Emission Lab (ZEL). Moreover, the feasibility of alternative fuels for frigates and capital ships appears to be the ultimate challenge as these ships are volume critical and cannot afford a reduction of their range with a factor two. The first step to reduce environmental impact for combatants is to limit their energy requirement by a combination of technological improvements and changes in the operational doctrine and crew behaviour, which 
can also lead to an increased endurance. The second step that is required to achieve the $70 \%$ reduction by 2050 requires more revolutionary approaches or an alternative energy dense fuel. However, the application of power supply from methanol engines on the support vessels can reduce the dependancy on fossil fuels and the associated $\mathrm{CO}_{2}$ emissions of the Royal Netherlands Navy by approximately $7 \%$ for all of its operations, thus contributing significantly to the societal challenge of limiting global warming.

\section{Acknowledgement}

This work has been funded by the Netherlands Ministry of Defence in a concept study for the replacement programme of the support vessels. MARIN has performed the analysis with the Ship Power and Energy Concept (SPEC) design methodology and developed the methodology. The Royal Netherlands Navy supplied Figure 1 and MARIN supplied Figure 3. Figure 4has been reproduced from (Andersson and Salazar. 2015) with permission.

\section{References}

Ammar, N. R., 2019. An environmental and economic analysis of methanol fuel for a cellular container ship. In: Transportation research part D. Vol. 69. pp. 66-76.

Andersson, K., Salazar, C. M., October 2015. Methanol as a marine fuel report. Tech. rep., Methanol Institute.

Defensie, 2018. Defensienota 2018: Investeren in onze mensen, slagkracht en zichtbaarheid. Tech. rep., Netherlands Ministry of Defence.

Deniz, C., Zincir, B., 2016. Envionmental and economic assesment of alternative marine fuels. In: Journal of Cleaner production. Vol. 113. pp. 438-449.

European Union, 2018. Directive (eu) 2018/2001 of the european parliament and of the council on the pro,motion of the use of energy from renewable sources. In: Official Journal of teh EUropean Union. Vol. L328. pp. 82-209.

Evrin, R. A., Dincer, I., 2019. Thermodynamic analysis and assessment of an integrated hydrogen fuel cell system for ships. In: International Journal of Hydrogen Energy. Vol. 44. pp. 6919-6928.

Geertsma, R. D., Negenborn, R. R., Visser, K., Hopman, J. J., 2017a. Design and control of hybrid power and propulsion systems for smart ships: a review of developments. In: Applied Energy. Vol. 194. pp. 30-54.

Geertsma, R. D., Negenborn, R. R., Visser, K., Hopman, J. J., 2017b. Pitch control for ships with mechanical and hybrid propulsion: Modelling, validation and performance quantification. In: Applied Energy. Vol. 206. pp. 1609-1631.

IMO MEPC 72, 2018. Initial strategy on greenhouse gas emissions reduction for ships. Tech. rep., International Maritime Organisation (IMO), April.

Kalikatzarakis, M., Geertsma, R. D., Boonen, E.-J., Visser, K., Negenborn, R. R., 2018. Ship energy management for hybrid propulsion and power supply with shore charging. In: Control Engineering Practice. Vol. 76. pp. 133-154.

Mutarraf, M. U., Terriche, Y., Niazi, K. A. K., Vasquez, J. C., Guerrero, J. M., 2018. Energy storage systems for shipboard microgrids - a review. In: Energies. Vol. 11.

Netherlands Ministry of Defence, 2015. Operational energy strategy. Tech. rep., Rijksoverheid.

Psoma, A., Sattler, G., 2002. Fuel cell systems for submarines: from the first idea to serial production. In: Journal of Power Sources. Vol. 106. pp. 381-383.

Schulten, P. J. M., Bongartz, J. M. T., Posthumus, C. J. C. M., Barendregt, I. P., June 2015. Energy as a weapon, the why and how of the energy-efficient ship. In: Proceedings of the Engine As A Weapon VI Conference. Bristol, UK.

Schulten, P. J. M., Geertsma, R. D., Visser, K., 2017. Energy as a weapon, part 2. In: Proceedings of the Engine As A Weapon VII conference. Bristol, UK.

Svanberg, M., Ellis, J., Lundgren, J., Landalv, I., 2018. Renewable methanol as a fuel for the shipping industry. In: Renewable and sustainable energy reviews. Vol. 94. pp. 1217-1228.

Taljegard, M., Brynolf, S., Grahn, M., Andersson, K., Johnson, H., 2014. Cost-effective choices of marine fuels in a carbon-constrained world: results from a global energy model. In: Environmental Science and Technology. Vol. 48. pp. 12986-12993.

Tronstad, T., Astrand, H. H., Haugom, G. P., Langfeldt, L., January 2017. Study on the use of fuel cells in shipping. Tech. rep., DNV GL.

van Biert, L., Godjevac, M., Visser, K., Aravind, P. V., 2016. A review of fuel cell systems for maritime applications. In: Journal of Power Sources. Vol. 327. pp. 345-364.

van de Ketterij, R. G., 2018. Emissions reduction at the netherlands ministry of defence: Potential, possibilities and impact. In: Proceedings of the 14th International Naval Engineering Conference. Glasgow, UK. 